counter-ions, electrophoresis etc., and the consideration of different models to account for them.

The book is clearly written, but it is by no means easy going for anyone who is not a specialist in the field, and the authors make few concessions to the reader in em. phasizing and clarifying the experimental implications of their treatment. They state that the level of presentation is "that suitable for second year graduate students". This suggests that they have been exceptionally fortunate in their experience of such students, since few Ph.D. students in Great Britain would have the tenacity to work through it. Nor indeed would they find it a very encouraging experience if they did, since what emerges clearly is that in spite of much labour we are still far from explaining satisfactorily many experimental results.

The book is to be welcomed primarily as a valuable reference work on mathematical aspects of polyelectrolytes in solution and a useful guide to the recent literature.

A. HickLING

\section{INORGANIC POLYMERS}

Inorganic Polymers

Edited by F. G. A. Stone and W. A. G. Graham. Pp. xi+631. (New York: Academic Press, Inc.; London: Academic Press, Inc. (London), Ltd., 1962.) 139s. $6 d$.

TTHE successful use of silicones and the considerable technological interest centred on the production of materials able to stand severe thermal stress in the presence of chemicals, including air and moisture, has stimulated interest in the production and study of inorganic polymers. This book, which is a multi-author book, consists of a sequence of reviews covering some of the areas of present-day research in this field and is not a comprehensive account. After a chapter on the general properties of polymers by A. V. Tobolsky other chapters follow in an arbitrary manner on particular classes of polymer. Phosphorus (J. R. Van Wazer and C. F. Callis), sulphur (M. Schmidt), boron (A. L. McCloskey) and silicone (A. J. Barry and H. N. Beck) polymers are each discussed in separate chapters. Other chapters cover organo polymers of silicon, germanium, tin and lead (R. K. Ingham and H. Gilman), polymeric metal alkoxides, organo metalloxanes and organo-metalloxanosiloxanes (D. C. Bradley), co-ordination polymers (B. P. Block) and electron-deficient polymers (A. J. Leffler).

It is a book into which one can dip here and there for information about the kinds of polymers which have been synthesized and at times one feels quite stimulated at some of the unusual structures which have been pre. pared. It is well illustrated and printed and will be a good source of information from which to examine the original literature, which includes many patent publica. tions. It has, however, some of the faults which usually appear in a book written by many authors, lacking the coherence and greater overall critical approach which I should like to see. Only occasional chapters end with a summary, or with a forward-looking conclusion.

An important feature of many of these polymers is their difficulty of characterization, arising often from their relative insolubility in most solvents. This accentuates the need for the use of physical methods and I should have liked the book to have had a greater physical bias. To some extent this lack of physical bias is a reflexion of the field itself, but nevertheless a discussion of the present and potential uses of the techniques of electron. microscopy and electron diffraction which have boen so useful with organic polymers and the type of information obtainable from the use of modern spectroscopie methods would have been valuable.

More speculations about future directions and developments both of a technological and chemical nature would also have been worth while, and perhaps some mention of the electrical or semiconductor properties of some of these polymers, such as the nitrogen-sulphur polymer, thereby linking the chemical work to the very closely related solid-state physics field. The editors rightly comment that too great an emphasis on work pointed to a particular applied direction should not cause neglect of the contribution which such studies of inorganic polymers might make to chemistry generally. Let us hope that this book will at least provide a start for work in the right direction in this interesting field. The book has a vory large author- and subject-index for the particular areas covered. It is expensive.

D. Chapman

\section{POLYAMINO-ACIDS}

Polyamino Acids, Polypeptides and Proteins Proceedings of an International Symposium held at the University of Wisconsin, 1961. Edited by Mark A. Stahmann. Pp. xviii +394. (Madison: The University of Wisconsin Press, 1962.) 8 dollars.

WHEN confronted with yet another report of an international symposium, the reader may justifiably shudder. However, the present example is one of the welcome exceptions which prove the rule that many such reports serve little purpose and eventually might even be seriously harmful in removing the excuse for scientists attending international symposia and profiting from informal discussions at them. The differences between this book and the others just eriticized are that: (1) it has contributions from most of the groups working in a well-defined field; (2) the individual papers, although mainly repetition of work published elsewhere, contain fresh information and provide useful guides to rapid search of primary sources of information; (3) the printed discussions, presumably an edited fraction of what was actually said, make the reader aware of which points are controversial; (4) there is a proper index; (5) even if publication has not been notably rapid, it is tolerably prompt, bearing in mind the size of the book and the number of contributors.

Studies of synthetic polypeptides, produced by polymerization of $N$-carboxy- $\alpha$-amino-acid anhydrides with expulsion of carbon dioxide, have been especially useful in increasing our understanding of the physical properties of polypeptides and hence proteins. The mechanism of the synthesis, or rather its mechanisms in various circumstances, also poses fascinating problems. A fow papers in the symposium under review dealt with proteins themselves rather than synthetic polypeptides. The general scope can be seen from the division into five parts, namely, synthesis and chemical properties of poly- $\alpha$-amino-acids and polypeptides (6 papers), kinetics and mechanism of the polymerization reaction (3 papers), properties of polyamino-acids in solution (11 papers). protein and polypeptide structure (5 papers), biological properties of poly- $\alpha$-amino-acids (11 papers). There are already very useful reviews in the field, notably the book by Bamford, Elliott, and Hanby (1956) and long articles by Katchalski and Sela in Advances in Protein Ohemistry (Volumes 13 and 14), but this volume is a useful supplement to them.

G. W. KENNER

\section{DIAMOND: FROM AMULET TO TOOLROOM}

The History and Use of Diamond

By Prof. S. Tolansky. Pp. $166+21$ plates. (London: Methuen and Co., Ltd., 1962.) 30s. net.

THROUGHOUT the ages, diamond, easily the hardest of the gemstones, has been a source of fascination to mankind. Originally, diamond and other gemstones were prized for their rarity and durability, and worn as amulets. 